\title{
PROFESSIONALISM: DOMAIN GUEST EDITORS
}

\author{
Martha A. Mattingly, PhD, CYC-P
}

Dr. Mattingly, Professor Emerita, Applied Developmental Psychology, University of Pittsburgh, is a member of The Academy of Child and Youth Care Professionals (invited) and past vice-president of The Association for Child and Youth Care Practice (ACYCP). She has been instrumental in the development of the Competencies for Professional Child and Youth Work Practitioners, the international code of ethics for child and youth care, and served as reviewing editor for the Child and Youth Care Forum and the Journal of Child and Youth Care.

Martha has written and presented on stress, ethics, certification, and professional standards in child and youth care at regional, national, and international levels. She has received the Frances Vandivier Award for the"Support and Education of Child, Youth and Family Workers" from the Child Care Association of Pennsylvania (CCAP), the Outstanding Child and Youth Care Award "For Outstanding Service and Dedication to the Profession of Child and Youth Care Work" from the InterAssociation Child and Youth Care Conference, and the Distinguished Service Award from Association for Child and Youth Care Practice.

Dr. Mattingly is a licensed psychologist (PA) and certified child and youth care practitioner (CYC-P). She received her $\mathrm{PhD}$ in psychology from Duquesne University.

\section{Carol Stuart, $B A, B P H E, M E d, P h D$}

Carol's career began in residential care in Ontario, Canada and she has 35 years of experience across three provinces. She has worked within residential and community-based child and youth care organizations and been a faculty member at the Schools of Child and Youth Care with Grant MacEwan Community College (now University), University of Victoria, and Ryerson University. She is currently the Dean of Health and Human Services at Vancouver Island University.

Carol is the author of Foundations of Child and Youth Care (Kendall/Hunt Publishers, 2009) and the co-author of Right Here, Right Now: Life-space Intervention for Children and Youth (Pearson, Canada, 2011). She is the managing editor for the Relational Child and Youth Care Practice journal and has had a major role in developing the competencies and certification exams for child and youth care. She is a certified CYC in Alberta, Ontario, and internationally with the Child and Youth Care Certification Board (CYCCB), Inc. She was a founding board member for CYCCB, Inc. and is the founding president of the Child and Youth Care Educational Accreditation Board (CYCEAB) of Canada. 
Frank Eckles, BA, CYC-P, LCCA

Frank has been working with young people since 1970. Currently, he divides his time between direct practice, working with other professionals to raise practice standards, and providing professional development to practitioners.

Frank is the training director for the Academy for Competent Youth Work offering credentialing-based training to afterschool, residential, corrections and youth development practitioners across the country. He is the board president of the Child and Youth Care Certification Board (CYCCB) and executive director of the CYC Certification Institute. In 2006 Frank received the President's Award for"Special Achievement in the Field of Child and Youth Care" from the Association for Child and Youth Care Practice (ACYCP) and in 2009 the award for "Outstanding Achievement in the Field" from the Academy of Child and Youth Care Professionals.

Frank is certified as a child and youth care practitioner at the professional level (CYC-P), and has been a licensed child care administrator in Texas since 1993. He serves on a variety of board of directors including: Association for Child and Youth Care Practice, Texas Youth and Child Care Worker Association, Child and Youth Care Certification Board, and the Texas Early Care Professional Development System Advisory Committee. Frank has a bachelor degree in psychology from Texas A\&M University, and is currently enrolled in the education and human resource development master's program. 